\title{
Simultaneous Determination of Albendazole and Its Three Metabolites in Pig and Poultry Muscle by Ultrahigh-Performance Liquid Chromatography-Fluorescence Detection
}

\author{
Zhaoyuan He ${ }^{1,2}$, Zhixiang Diao ${ }^{1,2}$, Yawen Guo ${ }^{1,2}$, Kaizhou Xie ${ }^{1,2, *}$, Lan Chen ${ }^{2,3}$, Chun Xue ${ }^{1,2}$, Yang Lu ${ }^{1,2}$, \\ Jinyuan Chen ${ }^{1,2}$ and Tao Zhang ${ }^{1,2}$ D \\ 1 College of Animal Science and Technology, Yangzhou University, Yangzhou 225009, China; \\ MZ120191027@yzu.edu.cn (Z.H.); 18352764521@163.com (Z.D.); DX120200135@yzu.edu.cn (Y.G.); \\ xuechun0727@163.com (C.X.); luyangbisheng@163.com (Y.L.); MZ120191044@yzu.edu.cn (J.C.); \\ zhangt@yzu.edu.cn (T.Z.) \\ 2 Joint International Research Laboratory of Agriculture \& Agri-Product Safety, Yangzhou University, \\ Yangzhou 225009, China; DZ120200026@yzu.edu.cn \\ 3 College of Veterinary Medicine, Yangzhou University, Yangzhou 225009, China \\ * Correspondence: kzxie@yzu.edu.cn; Tel.: +86-139-5275-0925
}

check for updates

Citation: He, Z.; Diao, Z.; Guo, Y.; Xie, K.; Chen, L.; Xue, C.; Lu, Y.; Chen, J.; Zhang, T. Simultaneous

Determination of Albendazole and Its Three Metabolites in Pig and Poultry Muscle by Ultrahigh-Performance Liquid Chromatography-Fluorescence Detection. Foods 2021, 10, 2350. https://doi.org/10.3390/foods10102350

Academic Editor: Evaristo Ballesteros

Received: 26 August 2021

Accepted: 29 September 2021

Published: 2 October 2021

Publisher's Note: MDPI stays neutral with regard to jurisdictional claims in published maps and institutional affiliations.

Copyright: (c) 2021 by the authors. Licensee MDPI, Basel, Switzerland. This article is an open access article distributed under the terms and conditions of the Creative Commons Attribution (CC BY) license (https:// creativecommons.org/licenses/by/ $4.0 /)$

\begin{abstract}
A fast, simple and efficient ultrahigh-performance liquid chromatography-fluorescence detection (UPLC-FLD) method for the determination of residues of albendazole (ABZ) and its three metabolites, albendazole sulfone ( $\left.\mathrm{ABZ}-\mathrm{SO}_{2}\right)$, albendazole sulfoxide (ABZ-SO), and albendazole-2aminosulfone (ABZ-2NH$-\mathrm{NH}_{2}$ ), in pig and poultry muscle (chicken, duck and goose) was established. The samples were extracted with ethyl acetate, and the extracts were further subjected to cleanup by utilizing a series of liquid-liquid extraction (LLE) steps. Then, extracts were purified by OASIS ${ }^{\circledR}$ PRiME hydrophilic-lipophilic balance (HLB) solid-phase extraction (SPE) cartridges $(60 \mathrm{mg} / 3 \mathrm{~mL})$. The target compounds were separated on an ACQUITY UPLC ${ }^{\circledR} \mathrm{BEH} \mathrm{C}_{18}(2.1 \mathrm{~mm} \times 100 \mathrm{~mm}, 1.7 \mu \mathrm{m})$ chromatographic column, using a mobile phase composed of $31 \%$ acetonitrile and $69 \%$ aqueous solution (containing $0.2 \%$ formic acid and $0.05 \%$ triethylamine). The limits of detection (LODs) and limits of quantification (LOQs) of the four target compounds in pig and poultry muscle were $0.2-3.8 \mu \mathrm{g} / \mathrm{kg}$ and $1.0-10.9 \mu \mathrm{g} / \mathrm{kg}$, respectively. The recoveries were all above $80.37 \%$ when the muscle samples were spiked with the four target compounds at the LOQ, 0.5 maximum residue limit (MRL), 1.0 MRL, and 2.0 MRL levels. The intraday relative standard deviations (RSDs) were less than $5.11 \%$, and the interday RSDs were less than $6.29 \%$.
\end{abstract}

Keywords: ultrahigh-performance liquid chromatography-fluorescence detection (UPLC-FLD); albendazole (ABZ) and its three metabolites; pig muscle; poultry muscle

\section{Introduction}

Albendazole (ABZ) is a benzimidazole drug and a broad-spectrum, highly effective anthelmintic drug widely used in veterinary clinics. ABZ is metabolized into its major active metabolites albendazole sulfone $\left(\mathrm{ABZ}-\mathrm{SO}_{2}\right)$, albendazole sulfoxide (ABZ-SO) and albendazole-2-aminosulfone ( $\left.\mathrm{ABZ}-2 \mathrm{NH}_{2}-\mathrm{SO}_{2}\right)$ in animals. The chemical structures of $\mathrm{ABZ}$, $\mathrm{ABZ}-\mathrm{SO}_{2}, \mathrm{ABZ}-\mathrm{SO}$, and $\mathrm{ABZ}-2 \mathrm{NH}_{2}-\mathrm{SO}_{2}$ are shown in Figure 1.

With increasing large-scale breeding, various parasitic diseases are seriously hindering economic output in the animal husbandry industry [1]. Many kinds of parasites infect animals, and parasites can parasitize various organs and tissues. ABZ has a good effect on gastrointestinal nematodes, lung nematodes, worms, and ectoparasites in pigs [2,3]. This drug is especially effective against Ascaridia galli and other worms in chickens [4]. Therefore, in many countries, ABZ is often used to treat these infections. However, some breeders do not use these drugs according to regulations, and abuse them in pursuit of greater economic benefits. These behaviors cause large amounts of these drugs to remain 
in animal-derived foods, such as muscle, fat, and internal organs, which can endanger the health of consumers [5]. In addition, animal toxicological studies have shown that ABZ and its metabolites may cause malformations and embryonic lethality [6,7]. Therefore, it is necessary to develop efficient and rapid detection methods for residues of ABZ and its three metabolites in animal products, to avoid harming consumer health. Most countries have stipulated the maximum residue limit (MRL) of ABZ in animal products [8,9]. The Ministry of Agriculture and Rural Affairs of the People's Republic of China, the Codex Alimentarius Commission (CAC), and the European Union (EU) have stipulated that the MRL of ABZ in the muscles of all edible animals should not exceed $100 \mu \mathrm{g} / \mathrm{kg}$, and the limit of the ABZ residue is based on the sum of ABZ and its three metabolites. This study adopted an MRL of $100 \mu \mathrm{g} / \mathrm{kg}$ in animal muscle as the standard, and developed a simultaneous detection method of ABZ and its three metabolites in pig and poultry muscle.<smiles>CCCSc1ccc2nc(NC(=O)OC)[nH]c2c1</smiles>

Albendazole<smiles>CCCS(=O)c1ccc2nc(NC(=O)OC)[nH]c2c1</smiles>

Albendazole sulfoxide<smiles>CCCS(=O)(=O)c1ccc2nc(NC(=O)OC)[nH]c2c1</smiles>

Albendazole sulfone<smiles>CCCS(=O)(=O)c1ccc2nc(N)[nH]c2c1</smiles>

Albendazole-2-aminosulfone

Figure 1. Structural formulas of $\mathrm{ABZ}, \mathrm{ABZ}-\mathrm{SO}_{2}, \mathrm{ABZ}-\mathrm{SO}$, and $\mathrm{ABZ}-2 \mathrm{NH}_{2}-\mathrm{SO}_{2}$.

Many quantitative methods, such as high-performance liquid chromatography-ultraviolet detection (HPLC-UV) [10,11], high-performance liquid chromatography-fluorescence detection (HPLC-FLD) [12-16], and liquid chromatography-mass spectrometry (LC-MS) [17-21], have been established for the simultaneous detection of ABZ and its metabolites in foodproducing animals. Among these methods, the most widely used has been LC-MS because of its high sensitivity and accuracy. However, LC-MS instruments are very expensive, causing the detection cost to be relatively high, and high-purity reagents and highly trained operators are strictly required. The HPLC-FLD method is time-consuming and has low detection efficiency, and some HPLC-FLD studies could not quantify all metabolites of ABZ. The detection process was very difficult and complicated when gas chromatography-mass spectrometry methods were used to determine ABZ and its metabolites, due to the basic nature and low volatility of these substances. The sensitivity of HPLC-UV was also not high enough [17]. It is very important to develop accurate, stable, and low-cost detection methods. At present, to our knowledge, there is no report on the simultaneous detection of $\mathrm{ABZ}$ and its three metabolites in pig or poultry muscle by ultrahigh-performance liquid chromatography-fluorescence detection (UPLC-FLD). Therefore, this study intended to develop a rapid, easy, and reliable UPLC-FLD method using liquid-liquid extraction (LLE) combined with solid-phase extraction (SPE) technology as a sample preparation technique to establish simultaneous detection of ABZ and its three metabolite residues in pig and poultry muscle (chicken, duck, goose). 


\section{Materials and Methods}

\subsection{Standards and Reagents}

ABZ (CAS No. 54965-21-8, purity $\geq 98.0 \%$ ), ABZ-SO 2 (CAS No. 75184-71-3, purity $\geq 99.0 \%$ ), and ABZ-SO (CAS No. $54029-12-8$, purity $\geq 98.0 \%$ ) were purchased from Sigma-Aldrich (MO, USA). ABZ-2 $\mathrm{NH}_{2}-\mathrm{SO}_{2}$ (CAS No. 80983-34-2, purity $\geq 99.8 \%$ ) was obtained from TMstandard (Changzhou, China).

HPLC-grade formic acid (purity $\geq 98 \%$ ), trimethylamine (purity $\geq 99 \%$ ), methanol (purity $\geq 99.9 \%$ ) and acetonitrile (purity $\geq 99.9 \%$ ) were purchased from Tokyo Chemical Industry (Tokyo, Japan), Thermo Fisher Scientific (MA, USA), and Merck (Darmstadt, Germany). Analytical-grade ethyl acetate, $\mathrm{n}$-hexane and ammonia were supplied by Sinopharm Chemical Reagent Co. (Shanghai, China). The experimental water was ultrapure water (the resistivity reached $18.2 \mathrm{M} \Omega \times \mathrm{cm}, 25^{\circ} \mathrm{C}$ ).

\subsection{Equipment}

An ACQUITY UPLC System (Waters Corp, Milford, MA, USA) coupled to a fluorescence detector (Waters Corp, Milford, MA, USA) was used. Data acquisitions were performed by Empower 3 software.

Other equipment, such as an EnSpire multimode plate reader (PerkinElmer, Waltham, MA, USA), P300H-type ultrasonic cleaner (Elma, Munich, Germany), Vortex-Genie 2 vortex oscillator (Scientific Industries, MA, USA), N-Evap 112 nitrogen blower (Organomation, Columbus, OH, USA), 5810R high-speed refrigerated centrifuge (Eppendof, Hamburg, Germany), JJ-2/FK-A tissue homogenizer (Jiangsu Kexi Instrument Co., Ltd., Jiangsu, China), and AX205 analytical balance (Mettler-Toledo, Zurich, Switzerland), were also used in this study.

\subsection{Standard Solutions}

Stock standard solutions of $\mathrm{ABZ}, \mathrm{ABZ}-\mathrm{SO}_{2}, \mathrm{ABZ}-\mathrm{SO}$ and $\mathrm{ABZ}-2 \mathrm{NH}_{2}-\mathrm{SO}_{2}$ were prepared by dissolving $2.5 \mathrm{mg}$ of individual analytes in $25 \mathrm{~mL}$ of methanol to obtain a final concentration of $100.0 \mu \mathrm{g} / \mathrm{mL}$. The stock standard solutions were stored stably for 3 months at $-70{ }^{\circ} \mathrm{C}$ in the dark. The solutions required shaking for the analytes to fully dissolve, and sonication was applied to assist ABZ dissolution.

Working standard solutions $(10.0,1.0$, and $0.1 \mu \mathrm{g} / \mathrm{mL})$ of $\mathrm{ABZ}, \mathrm{ABZ}-\mathrm{SO}_{2}, \mathrm{ABZ}-\mathrm{SO}$ and $\mathrm{ABZ}-2 \mathrm{NH}_{2}-\mathrm{SO}_{2}$ were prepared by diluting the stock standard solution $(100.0 \mu \mathrm{g} / \mathrm{mL})$ of each compound with acetonitrile and $0.2 \%$ formic acid aqueous solution containing $0.05 \%$ triethylamine $(31: 69, v / v)$. The working standard solutions were stored stably for 3 months at $-34{ }^{\circ} \mathrm{C}$ in the dark.

\subsection{Blank Samples and Sample Preparation}

This study was conducted in accordance with the ethics requirements of the official ethical committee of our university. Muscle samples were obtained from chickens, ducks, geese, and a pig, none of which had received any medication. The samples were stored at $-34^{\circ} \mathrm{C}$ in a refrigerator after they were homogenized with a tissue homogenizer.

Two grams of homogeneous blank muscle were accurately weighed in $50 \mathrm{~mL}$ polypropylene centrifuge tubes after thawing. Samples were spiked with $15 \mathrm{~mL}$ of ethyl acetate, vortexed for $5 \mathrm{~min}$ by a vortex oscillator, ultrasonically extracted for $5 \mathrm{~min}$, and centrifuged for $10 \mathrm{~min}$ at $12,000 \mathrm{rpm}\left(4^{\circ} \mathrm{C}\right)$. The supernatant was transferred into a new centrifuge tube after centrifugation. Subsequently, the precipitate was again extracted as before, and the supernatant was combined with that from the first extraction. The supernatants were blown to near dryness with nitrogen. The residue sample was dissolved in $5 \mathrm{~mL}$ of mobile phase and spiked with $15 \mathrm{~mL}$ of n-hexane saturated with acetonitrile for degreasing. Then, the sample was vortexed for $2 \mathrm{~min}$ and centrifuged for $5 \mathrm{~min}$ at $6000 \mathrm{rpm}\left(4^{\circ} \mathrm{C}\right)$. Subsequently, the n-hexane layer was discarded, and the supernatant was collected. After OASIS ${ }^{\circledR}$ PRiME HLB SPE cartridges $(60 \mathrm{mg} / 3 \mathrm{~mL}$, Waters Corp, USA) were conditioned by $3 \mathrm{~mL}$ of methanol and $3 \mathrm{~mL}$ of ultrapure water, the supernatant was purified by OASIS ${ }^{\circledR}$ 
PRiME HLB SPE cartridges. Then, the samples were eluted sequentially with $3 \mathrm{~mL}$ of mobile phase and $3 \mathrm{~mL}$ of $20 \%$ ammoniated methanol (ammonia water:methanol = 2:8, $v / v)$, and the eluate solution was collected into $10 \mathrm{~mL}$ centrifuge tubes. The eluate solution was blown to near dryness with nitrogen. The residue sample was reconstituted with $2.0 \mathrm{~mL}$ of mobile phase, and the mixture was vortexed at low speed for $1 \mathrm{~min}$. Finally, the samples were passed through a hydrophilic PTFE type $(13 \mathrm{~mm} \times 0.22 \mu \mathrm{m})$ needle (Thermo Fisher Scientific, USA), and the filtrate was analyzed by UPLC-FLD.

\subsection{UPLC-FLD Analysis}

A UPLC system equipped with a fluorescence detector was employed. Compound separation was executed on an ACQUITY UPLC ${ }^{\circledR}$ BEH C $_{18}(2.1 \mathrm{~mm} \times 100 \mathrm{~mm}, 1.7 \mu \mathrm{m})$ chromatographic column (Waters Corp, USA) connected to a VanGuard ${ }^{\mathrm{TM}}$ BEH C18 $(2.1 \mathrm{~mm} \times 5 \mathrm{~mm}, 1.7 \mu \mathrm{m})$ guard column (Waters Corp, USA) with an appropriate column temperature of $35^{\circ} \mathrm{C}$. Mobile phase A was acetonitrile, and mobile phase B consisted of $0.2 \%$ formic acid aqueous solution containing $0.05 \%$ trimethylamine. Mobile phases A and B were degassed quickly for $20 \mathrm{~min}$ by an ultrasonic cleaner before they were used. Isocratic elution was utilized in the method, and the ratio of mobile phases A and B was 31:69 $(v / v)$. The flow rate was $0.25 \mathrm{~mL} / \mathrm{min}$, and the injection volume was $5 \mu \mathrm{L}$. The total run time was $6 \mathrm{~min}$. The excitation wavelength and emission wavelength of the four compounds were 286 and $335 \mathrm{~nm}$, respectively.

\subsection{Method Validation}

The procedure of the UPLC-FLD method was validated by referring to the requirements of the EU [22]. The validation criteria involved sensitivity, linearity, recovery and precision.

\subsubsection{Sensitivity}

The sensitivity of the method was assessed in terms of the LODs and LOQs. When the signal-to-noise ratio $(S / N) \geq 3$, the corresponding additive concentration was the LOD of the analytical method. When $S / N \geq 10$, the corresponding additive concentration was the LOQ of the analytical method; at the same time, the concentration met the accuracy and precision requirements (recovery $\geq 70 \%$, relative standard deviation (RSD) $\leq 20 \%$ ). The working standard solutions of $\mathrm{ABZ}, \mathrm{ABZ}-\mathrm{SO} \mathrm{O}_{2}, \mathrm{ABZ}-\mathrm{SO}$ and $\mathrm{ABZ}-2 \mathrm{NH}_{2}-\mathrm{SO}_{2}$ were diluted stepwise with each blank muscle matrix extract solution to give solutions of different concentrations. Then, each concentration of the four compounds when $S / N \geq 3$ and $\mathrm{S} / \mathrm{N} \geq 10$ was detected 3 times by UPLC-FLD, and the average $\mathrm{S} / \mathrm{N}$ was obtained.

\subsubsection{Linearity}

Mobile phases A and B $(31: 69, v / v)$ were used to dilute the working standard solutions of ABZ, ABZ-SO, $\mathrm{ABZ}-\mathrm{SO}$ and $\mathrm{ABZ}-2 \mathrm{NH}_{2}-\mathrm{SO}_{2}$ to a series of concentrations $(10.0,20.0,25.0$, 50.0, 100.0, 200.0 and 400.0 $\mu \mathrm{g} / \mathrm{L}$ for ABZ; 1.0, 10.0, 25.0, 50.0, 100.0, 200.0 and $400.0 \mu \mathrm{g} / \mathrm{L}$ for $\mathrm{ABZ}-\mathrm{SO}_{2} ; 8.0,10.0,25.0,50.0,100.0,200.0$ and $400.0 \mu \mathrm{g} / \mathrm{L}$ for ABZ-SO; and 1.5, 10.0, 25.0, 50.0, 100.0, 200.0 and $400.0 \mu \mathrm{g} / \mathrm{L}$ for $\mathrm{ABZ}-2 \mathrm{NH}_{2}-\mathrm{SO}_{2}$ ), and these solutions were then analyzed 5 times by the optimized UPLC-FLD method. Calibration curves were prepared using the peak areas as the ordinate $(\mathrm{Y})$ and the concentrations of the working solutions as the abscissa $(X)$.

\subsubsection{Recovery and Precision}

The recovery and precision were determined by analyzing blank muscle samples spiked with each compound in six replicates at the LOQ, 0.5 MRL, 1.0 MRL and 2.0 MRL levels. Recoveries were determined by comparing the chromatographic peak areas of extracted analytes from calibration curves of each compound. Precision, including intraday precision and interday precision, was evaluated by RSD. The intraday RSD was determined by analyzing blank muscle samples spiked with each compound in six replicates at the 
four concentration levels at different times on the same day, and the interday RSD was determined by analyzing blank muscle samples spiked with each compound in six replicates at the four concentration levels on different days.

\section{Results and Discussion}

3.1. Optimization of Chromatographic Conditions

\subsubsection{Selection of a Chromatographic Column}

The chromatographic column plays a key role in successful analysis and is responsible for separation in an LC system. Based on previous reports on the detection of ABZ and its metabolites in animal-derived foods, the most commonly used chromatographic column was the $\mathrm{C}_{18}$ column $[14,15]$. In this study, HSS T3, CSH C $18, \mathrm{BEH} \mathrm{C}_{18}$ and Shield RP18 columns were tested.

Initially, regardless of flow rate, column temperature and other related parameters, the chromatographic peaks of ABZ-SO and $\mathrm{ABZ}-2 \mathrm{NH}_{2}-\mathrm{SO}_{2}$ could not be separated well when the HSS T3 column or $\mathrm{CSH} \mathrm{C}_{18}$ column was used for analysis, and overlapping peaks were generated. Therefore, separation could not be achieved using the HSS T3 or CSH $\mathrm{C}_{18}$ column. A series of sharp solvent peaks appeared when the Shield RP18 column was used, which resulted in the loss of the ABZ-SO peak. Finally, the ACQUITY UPLC ${ }^{\circledR}$ BEH C 18 chromatographic column was selected as the analytical column for this study. The peak shapes of the four target compounds were sharp and symmetric, optimal separation was achieved, and the peaks were not interfered with by peaks of impurities in the sample tissue. The analysis time was $6 \mathrm{~min}$, and detection could be completed quickly under optimized UPLC-FLD conditions and using a $\mathrm{BEH} \mathrm{C}_{18}$ column.

\subsubsection{Optimization of the Mobile Phase}

The composition of the mobile phase has a substantial influence on the separation and peak shape of analytes. In relevant studies on the simultaneous detection of $\mathrm{ABZ}$ and its three metabolites in animal-derived foods, at present, the water (containing a small amount of organic acid)-acetonitrile [17-19] mobile phase system and the water (containing a small amount of formic acid)-methanol [21-23] mobile phase system are frequently used. In this study, when $69 \%$ water (containing $0.2 \%$ formic acid and $31 \%$ methanol was used as the mobile phase, the chromatogram showed large fluctuations at 4-6 min in the gradient elution procedure, which caused the ABZ peak to be lost. When $69 \%$ water (containing $0.2 \%$ formic acid) and $31 \%$ acetonitrile was selected as the mobile phase, high responses and sharp peak shapes were obtained for ABZ, ABZ-SO, $\mathrm{ABZ}-\mathrm{SO}$ and $\mathrm{ABZ}-2 \mathrm{NH}_{2}-\mathrm{SO}_{2}$. Other concentrations of formic acid were not tested because the effect of $0.2 \%$ formic acid was good. Moreover, the separation effects of six different ratios of water (containing $0.2 \%$ formic acid)-acetonitrile mobile phase systems (75:25, 73:27, 71:29, 69:31, 67:33, 65:35, v/v) were investigated. When the mobile phase ratio was 69:31, the baseline chromatogram was stable, there were no solvent peaks, and the separation effects of each target were optimal. However, the chromatographic peak had a small tail, which may be because ABZ and its three metabolites are weakly alkaline substances and are prone to ionization. An appropriate amount of triethylamine added to mobile phase B can inhibit ionization, relieve the phenomenon of chromatographic peak tailing, and yield good chromatographic peaks. The addition of different amounts $(0.01 \%, 0.03 \%, 0.05 \%, 0.07 \%$ and $0.09 \%)$ of triethylamine to relieve the chromatographic peak tailing phenomenon was also examined. The peaks of each target analyte were symmetrical when the concentration of triethylamine was $0.05 \%$. Thus, the study used $0.2 \%$ formic acid aqueous solution (containing $0.05 \%$ triethylamine)acetonitrile $(69: 31, v / v)$ as the mobile phase for isocratic elution. Compared to the gradient elution procedures used in other methods, the isocratic elution procedure was simple and stable in this method. 


\subsubsection{Optimization of Column Temperature and Flow Rate}

Proper column temperature can promote the separation effect of the target analytes and eliminate the influence of environmental temperature changes. In this study, the chromatographic peak shapes of four target compounds were tested at different chromatographic column temperatures $\left(25^{\circ} \mathrm{C}, 30^{\circ} \mathrm{C}, 31^{\circ} \mathrm{C}, 33^{\circ} \mathrm{C}, 35^{\circ} \mathrm{C}, 37^{\circ} \mathrm{C}\right.$ and $\left.40^{\circ} \mathrm{C}\right)$. First, different column temperatures $\left(25^{\circ} \mathrm{C}, 30^{\circ} \mathrm{C}, 35^{\circ} \mathrm{C}\right.$ and $\left.40{ }^{\circ} \mathrm{C}\right)$ were compared. When the column temperature was under $30^{\circ} \mathrm{C}$, the retention times of the target analytes were delayed. When the column temperature was set to $40{ }^{\circ} \mathrm{C}$ or higher, the peak shape of the target analytes improved, but separation of the ABZ-SO and $\mathrm{ABZ}-2 \mathrm{NH}_{2}-\mathrm{SO}_{2}$ peaks was affected. Moreover, high temperatures caused irreversible damage to the column. The column temperatures of $31^{\circ} \mathrm{C}, 33{ }^{\circ} \mathrm{C}, 35^{\circ} \mathrm{C}, 37^{\circ} \mathrm{C}$ and $39^{\circ} \mathrm{C}$ were then compared. Ultimately, the retention times and separation of the target analytes were optimal when the column temperature was $35^{\circ} \mathrm{C}$. Therefore, a column temperature of $35^{\circ} \mathrm{C}$ was selected in this study.

The column pressure of a chromatographic column increases with increasing flow rate. Decreasing the flow rate can prolong the analysis time. The effect of flow rate on the retention time of the target compounds was examined. Finally, the optimal flow rate was selected as $0.25 \mathrm{~mL} / \mathrm{min}$ according to the separation and retention time of the target compounds.

\subsection{Chromatograms and Determination of Detection Wavelengths}

Good chromatograms (Figures 2-5) were obtained by using the optimized UPLC-FLD conditions. As shown in Figures 2-5, the retention times of $\mathrm{ABZ}, \mathrm{ABZ}-\mathrm{SO}_{2}, \mathrm{ABZ}-\mathrm{SO}$ and $\mathrm{ABZ}-2 \mathrm{NH}_{2}-\mathrm{SO}_{2}$ were approximately $5.00,2.10,1.45$, and $1.20 \mathrm{~min}$, respectively. The peak shapes of the target compounds were well separated and did not overlap. The chromatographic peaks of the target compounds did not exhibit tailing and were not affected by impurity peaks.

Fluorescence detectors are highly selective detectors that are only suitable for detecting compounds containing fluorophores. Detection wavelengths (excitation wavelengths and emission wavelengths) are necessary parameters for fluorescence detection and can directly affect the sensitivity and selectivity of detection. According to some previous LC-FLD studies [12-16], the excitation wavelengths and emission wavelengths of ABZ and its three metabolites are 290 and $330 \mathrm{~nm}$ and 290 and $320 \mathrm{~nm}$, respectively. In this study, the detection wavelengths of the four target compounds were scanned by a multimode plate reader, and the scan results showed that the excitation wavelengths and emission wavelengths of $\mathrm{ABZ}, \mathrm{ABZ}-\mathrm{SO}_{2}, \mathrm{ABZ}-\mathrm{SO}$ and $\mathrm{ABZ}-2 \mathrm{NH}_{2}-\mathrm{SO}_{2}$ were 284.9 and $345.3 \mathrm{~nm}, 278.6$ and $327.9 \mathrm{~nm}$, 303.1 and $330.4 \mathrm{~nm}$ and 277.1 and $335.8 \mathrm{~nm}$, respectively. According to the sensitivities and responses of each target, the excitation wavelengths and emission wavelengths of the four target compounds were chosen as 286 and $335 \mathrm{~nm}$, respectively, after the different detection wavelengths of the four compounds were compared in this study. 

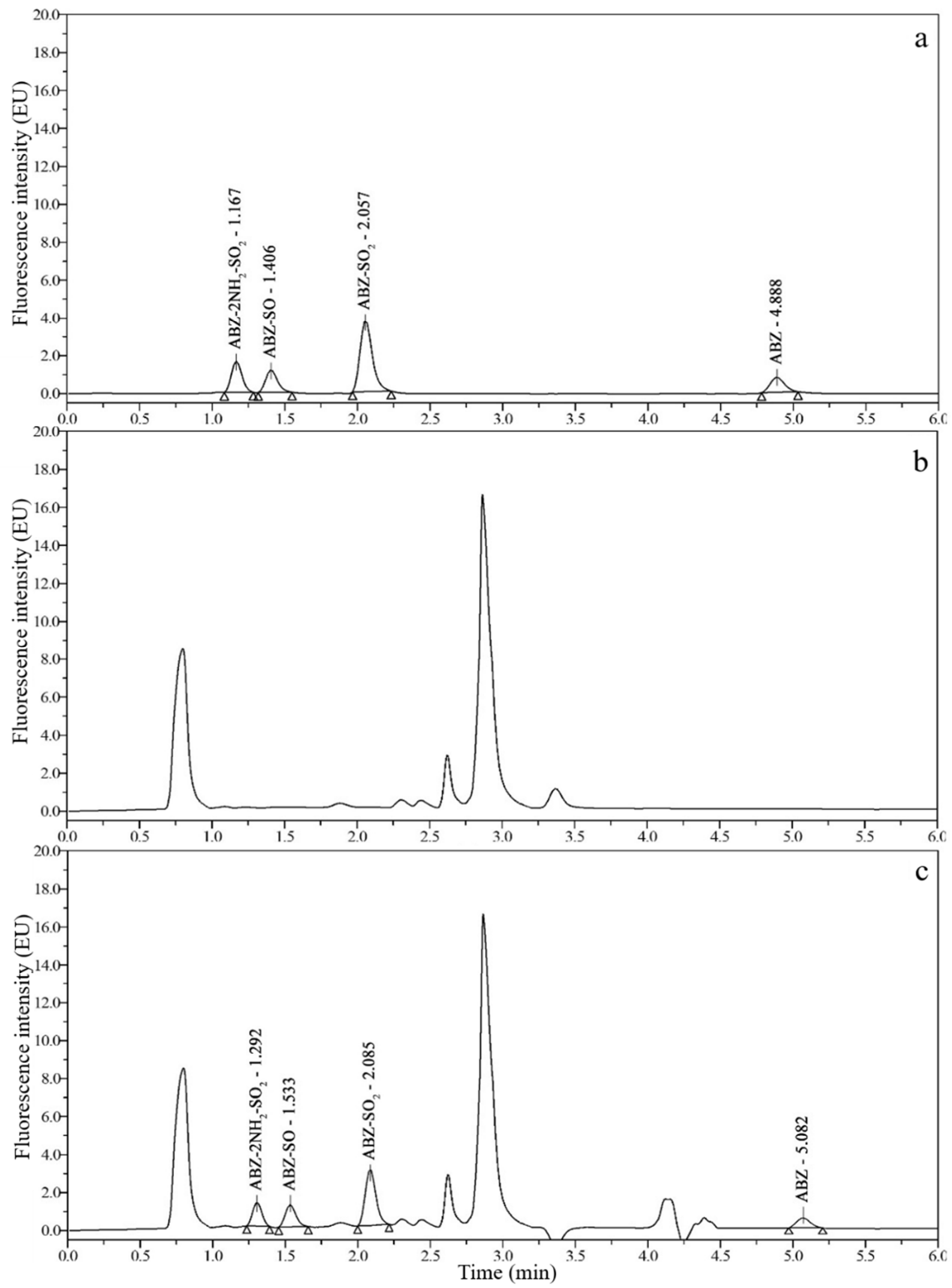

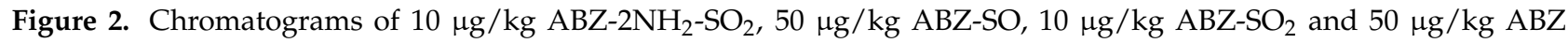

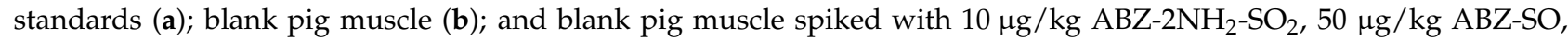
$10 \mu \mathrm{g} / \mathrm{kg} \mathrm{ABZ}-\mathrm{SO}_{2}$ and $50 \mu \mathrm{g} / \mathrm{kg}$ ABZ standards (c). 

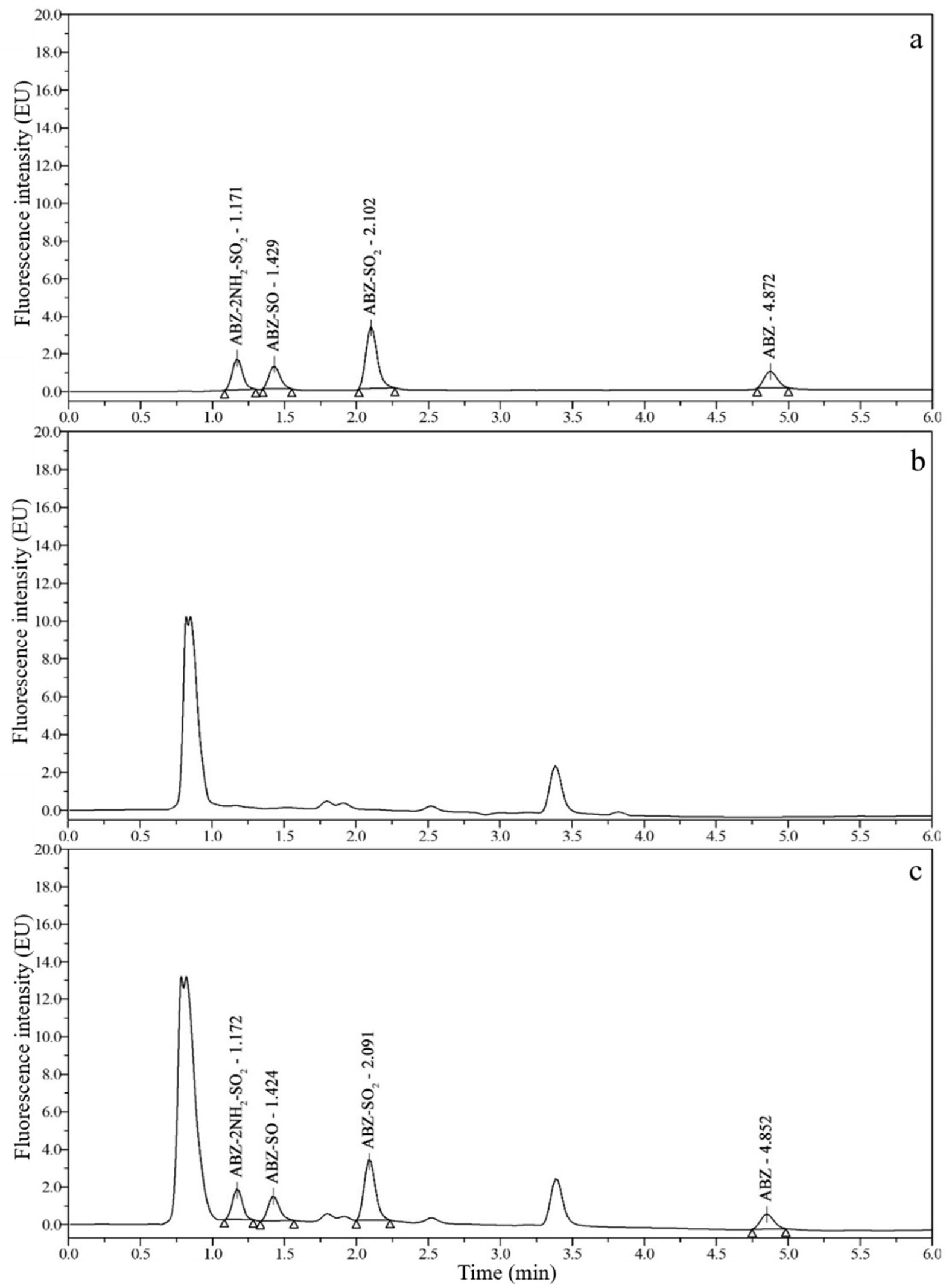

Figure 3. Chromatograms of $10 \mu \mathrm{g} / \mathrm{kg}$ ABZ-2NH $\mathrm{NH}_{2}-\mathrm{SO}_{2}, 50 \mu \mathrm{g} / \mathrm{kg}$ ABZ-SO, $10 \mu \mathrm{g} / \mathrm{kg}$ ABZ-SO 2 and $50 \mu \mathrm{g} / \mathrm{kg}$ ABZ standards

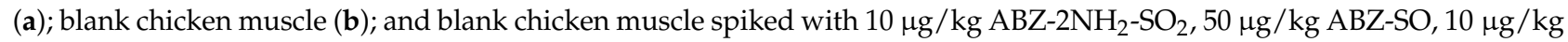
$\mathrm{ABZ}-\mathrm{SO}_{2}$ and $50 \mu \mathrm{g} / \mathrm{kg} \mathrm{ABZ}$ standards (c). 

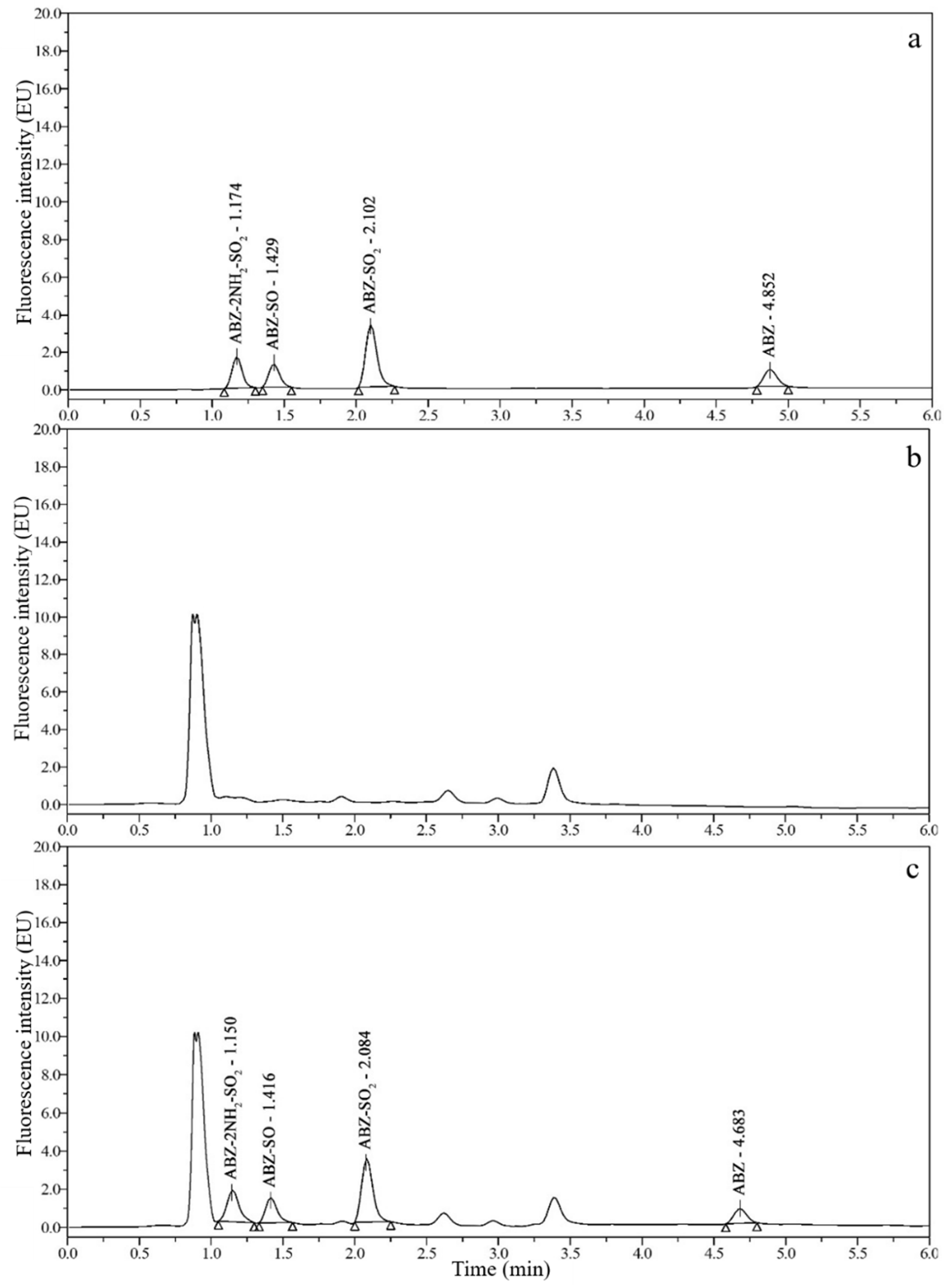

Figure 4. Chromatograms of $10 \mu \mathrm{g} / \mathrm{kg}$ ABZ-2NH $\mathrm{NH}_{2}-\mathrm{SO}_{2}, 50 \mu \mathrm{g} / \mathrm{kg} \mathrm{ABZ}-\mathrm{SO}, 10 \mu \mathrm{g} / \mathrm{kg}$ ABZ-SO 2 and $50 \mu \mathrm{g} / \mathrm{kg}$ ABZ standards

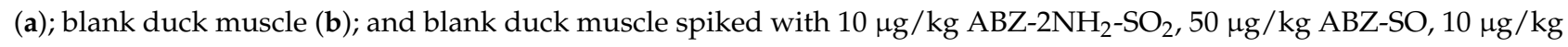
$\mathrm{ABZ}-\mathrm{SO}_{2}$ and $50 \mu \mathrm{g} / \mathrm{kg} \mathrm{ABZ}$ standards (c). 

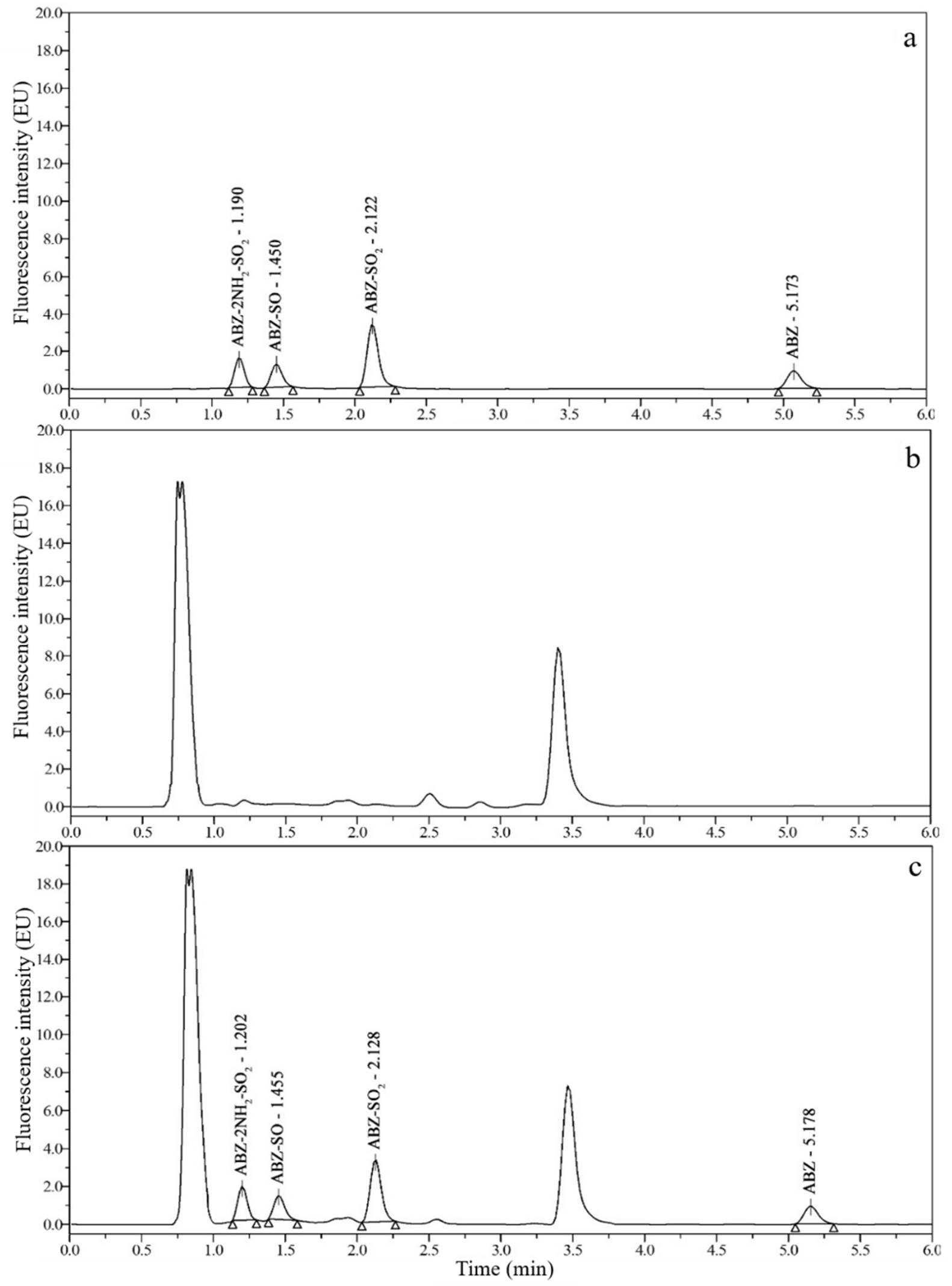

Figure 5. Chromatograms of $10 \mu \mathrm{g} / \mathrm{kg}$ ABZ- $2 \mathrm{NH}_{2}-\mathrm{SO}_{2}, 50 \mu \mathrm{g} / \mathrm{kg}$ ABZ-SO, $10 \mu \mathrm{g} / \mathrm{kg}$ ABZ-SO 2 and $50 \mu \mathrm{g} / \mathrm{kg}$ ABZ standards

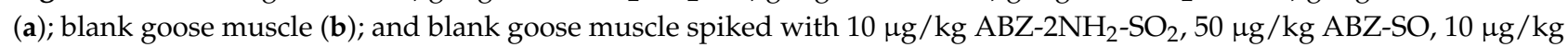
$\mathrm{ABZ}-\mathrm{SO}_{2}$ and $50 \mu \mathrm{g} / \mathrm{kg} \mathrm{ABZ}$ standards (c). 


\subsection{Optimization of Sample Preparation}

The choice of extractant for LLE was significant for the recovery of the four analytes from muscle samples and required both the ability to extract drugs and the ability to remove interfering substances in the sample matrix. ABZ and its three metabolites are all moderately polar molecules that are weakly alkaline. In previous studies, the most common solvent used to extract ABZ and its three metabolites in animal-derived foods was ethyl acetate $[24,25]$ or acetonitrile $[12,26]$. In this research, the extraction effects of ethyl acetate and acetonitrile as extractants were compared. According to the recovery rate results, the extraction effect of acetonitrile was good. However, due to the high polarity of acetonitrile, more endogenous substances were extracted from pig and poultry muscle, which caused the chromatographic peaks of the target substances to be interfered with by the peaks of impurities during UPLC-FLD analysis. Ethyl acetate is low in toxicity and highly volatile, which could save time during concentration and improve detection efficiency. When ethyl acetate was used as the extractant, these target compounds could be effectively extracted from the sample matrix with a high recovery; additionally, the peaks of the target compounds were not interfered with by the peaks of impurities in the sample tissue during UPLC-FLD analysis. Therefore, ethyl acetate was used as the extractant in this study. Moreover, to improve the recovery rate, samples were extracted one, two, or three times, and the recoveries were compared. Two extractions could effectively increase the recovery rate compared with one extraction. Three extractions did not significantly improve the recovery rate and wasted more reagents. Finally, the samples were extracted two times to optimize the recovery rate and environmental protection.

Relevant literature has reported on different types of SPE cartridges and purification procedures to purify extracted samples, and MCX cartridges [18] and $C_{18}$ cartridges [20,21] are commonly used. In this study, a comprehensive comparison of the purification effects of Waters Oasis MCX, ProElutAL-A acidic $\mathrm{Al}_{2} \mathrm{O}_{3}$, Cleanert $\mathrm{S} \mathrm{C}_{18}$ and Waters PRIME HLB cartridges was performed. When Waters Oasis MCX, Cleanert $\mathrm{S} \mathrm{C}_{18}$ and acidic $\mathrm{Al}_{2} \mathrm{O}_{3}$ cartridges were used for purification, the recoveries of $\mathrm{ABZ}$ and $\mathrm{ABZ}-2 \mathrm{NH}_{2}-\mathrm{SO}_{2}$ were significantly lower, and the purification effect was poor. The purification effect of the Waters PRIME HLB cartridges was good. There was no interference with the peaks of target compounds, and the recovery was high when Waters PRIME HLB cartridges were used. In addition, an oil-free vacuum pump and an antifogging glass vacuum tank were equipped during the SPE extraction process, which could avoid cross-contamination and improve the extraction efficiency.

A filter membrane was used to filter impurities and thus protect the chromatographic analysis system. A polyvinylidene fluoride (PVDF) hydrophobic syringe filter membrane, a hydrophilic polytetrafluoroethylene (PTFE) syringe filter membrane, an aqueous phase syringe filter membrane and an organic phase nylon syringe filter membrane were examined. The results showed that when the aqueous phase syringe filter membrane and PVDF syringe filter membrane were used, severe peak tailing occurred. The organic phase nylon syringe filter membrane had a large pore size and could not effectively filter out impurities. In contrast, the hydrophilic PTFE syringe filter membrane exhibited better performance. Not only did this filter provide clean extracts, but the recovery of the four compounds was also higher when a PTFE syringe filter membrane was used. Therefore, the hydrophilic PTFE syringe filter membrane $(13 \mathrm{~mm} \times 0.22 \mu \mathrm{m})$ was ultimately selected.

\subsection{Method Comparison}

To date, various analytical methods have been used for the simultaneous detection of ABZ and its three metabolites. However, to our knowledge, not all studies included ABZ and all three metabolites in the detection process, and there are no reports using a UPLCFLD method for the simultaneous detection of ABZ and its three metabolites in animalderived foods. Shaikh et al. [14] established an LC-FLD method for the determination of ABZ and its major metabolites in some fish muscles; the average recoveries were $67-94 \%$, and the detection time was $20 \mathrm{~min}$. Xu et al. [17] developed an LC-MS/MS method for 
determining mebendazole and its metabolites, $\mathrm{ABZ}$ and its metabolites, and levamisole in muscles of aquatic products. The recoveries of ABZ and its metabolites were $80.0-113.7 \%$, with an RSD less than $10.0 \%$, and the detection time was 10 min. Permana et al. [11] developed an HPLC-UV method determining ivermectin, $\mathrm{ABZ}, \mathrm{ABZ}-\mathrm{SO}_{2}, \mathrm{ABZ}-\mathrm{SO}$ and doxycycline in rat plasma and organs. The recoveries of $\mathrm{ABZ}, \mathrm{ABZ}-\mathrm{SO}_{2}$ and $\mathrm{ABZ}-\mathrm{SO}$ were $79.81-97.29 \%$, with an RSD less than $11.14 \%$, and the detection time was $20 \mathrm{~min}$. The UPLC-FLD method in this study could simultaneously detect the residues of ABZ and its three metabolites in pig and poultry muscle using LLE combined with SPE technology to extract target analytes and purify the sample matrix. The recoveries of ABZ and its three metabolites from all samples were $80.37-98.39 \%$, with an RSD less than $6.20 \%$, the LODs and LOQs were $0.2-3.8 \mu \mathrm{g} / \mathrm{kg}$ and $1.0-10.9 \mu \mathrm{g} / \mathrm{kg}$, respectively, and the detection time was completed within $6 \mathrm{~min}$. Compared with other methods, the most significant advantages of the UPLC-FLD method were a shorter detection time $(6 \mathrm{~min})$, which greatly improves work efficiency, and the RSDs were better than those of the LC-FLD, LC-MS/MS and HPLC-UV methods. Moreover, the extraction recovery and sensitivity were comparable to those of most methods. Thus, the study provides a new and advanced technology for the efficient and rapid detection of $\mathrm{ABZ}$ and its three metabolites in animal products.

\subsection{Validation Results of the Method}

We did not find a suitable internal standard before the beginning of the research. Therefore, we chose the external standard method for this study.

\subsubsection{Sensitivity}

The LODs and LOQs of ABZ and its three metabolites were examined in pig and poultry muscle in accordance with the method above. The determination results are listed in Table 1. As shown in Table 1, in pig and poultry muscle, the LOD of ABZ was $2.8-3.6 \mu \mathrm{g} / \mathrm{kg}$, and the LOQ was $10.0-10.9 \mu \mathrm{g} / \mathrm{kg}$; the LOD of ABZ-SO ${ }_{2}$ was $0.2-0.4 \mu \mathrm{g} / \mathrm{kg}$, and the LOQ was $1.0-1.5 \mu \mathrm{g} / \mathrm{kg}$; the LOD of ABZ-SO was $2.4-3.8 \mu \mathrm{g} / \mathrm{kg}$, and the LOQ was $8.0-9.7 \mu \mathrm{g} / \mathrm{kg}$; and the LOD of ABZ-2NH $\mathrm{NH}_{2}-\mathrm{SO}_{2}$ was $0.5-0.9 \mu \mathrm{g} / \mathrm{kg}$, and the LOQ was $1.5-3.0 \mu \mathrm{g} / \mathrm{kg}$.

Table 1. LODs and LOQs of ABZ, ABZ-SO, $\mathrm{ABZ}-\mathrm{SO}$ and $\mathrm{ABZ}-2 \mathrm{NH}_{2}-\mathrm{SO}_{2}$ in pig and poultry muscle.

\begin{tabular}{cccc}
\hline Analyte & Animal Matrix & LOD $(\mu \mathrm{g} / \mathbf{k g})$ & LOQ $(\mu \mathrm{g} / \mathbf{k g})$ \\
\hline \multirow{4}{*}{$\mathrm{ABZ}$} & Pig muscle & 2.8 & 10.0 \\
& Chicken muscle & 3.2 & 10.7 \\
& Duck muscle & 3.1 & 10.0 \\
& Goose muscle & 3.6 & 10.9 \\
& Pig muscle & 0.4 & 1.5 \\
$\mathrm{ABZ}^{-S O} \mathrm{SO}_{2}$ & Chicken muscle & 0.3 & 1.0 \\
& Duck muscle & 0.2 & 1.0 \\
& Goose muscle & 0.2 & 1.0 \\
& Pig muscle & 3.8 & 9.7 \\
$\mathrm{ABZ}-\mathrm{SO}$ & Chicken muscle & 3.0 & 8.3 \\
& Duck muscle & 2.4 & 8.0 \\
& Goose muscle & 2.5 & 8.5 \\
& Pig muscle & 0.9 & 3.0 \\
$\mathrm{ABZ}-2 \mathrm{NH}_{2}-\mathrm{SO}_{2}$ & Chicken muscle & 0.6 & 1.8 \\
& Duck muscle & 0.5 & 1.5 \\
& Goose muscle & 0.5 & 1.9 \\
\hline
\end{tabular}




\subsubsection{Linearity}

The peak areas and concentration of each drug had a good linear relationship when the concentration ranges of $\mathrm{ABZ}, \mathrm{ABZ}-\mathrm{SO}_{2}, \mathrm{ABZ}-\mathrm{SO}$ and $\mathrm{ABZ}-2 \mathrm{NH}_{2}-\mathrm{SO}_{2}$ were $10.0-400.0 \mu \mathrm{g} / \mathrm{L}$, $1.0-400.0 \mu \mathrm{g} / \mathrm{L}, 8.0-400.0 \mu \mathrm{g} / \mathrm{L}$ and $1.5-400.0 \mu \mathrm{g} / \mathrm{L}$, respectively. The linear ranges, linear regression equations and coefficients of determination $\left(\mathrm{R}^{2}\right)$ of $\mathrm{ABZ}, \mathrm{ABZ}-\mathrm{SO}_{2}, \mathrm{ABZ}-\mathrm{SO}$ and ABZ- $2 \mathrm{NH}_{2}-\mathrm{SO}_{2}$ are shown in Table 2.

Table 2. The linearity range, linear regression equation and determination coefficient of ABZ, ABZ$\mathrm{SO}_{2}, \mathrm{ABZ}-\mathrm{SO}$ and $\mathrm{ABZ}-2 \mathrm{NH}_{2}-\mathrm{SO}_{2}(\mathrm{n}=5)$.

\begin{tabular}{cccc}
\hline Analyte & $\begin{array}{c}\text { Linearity Range } \\
(\boldsymbol{\mu g} / \mathbf{L})\end{array}$ & $\begin{array}{c}\text { Linear Regression } \\
\text { Equation }\end{array}$ & $\begin{array}{c}\text { Determination } \\
\text { Coefficient }\left(\mathbf{R}^{\mathbf{2}}\right)\end{array}$ \\
\hline $\mathrm{ABZ}$ & $10.0-400.0$ & $\mathrm{y}=1355.7 \mathrm{x}+11,560$ & 0.9995 \\
$\mathrm{ABZ}-\mathrm{SO}$ & $1.0-400.0$ & $\mathrm{y}=32,757 \mathrm{x}+61,988$ & 0.9994 \\
$\mathrm{ABZ}-\mathrm{SO}$ & $8.0-400.0$ & $\mathrm{y}=2498.1 \mathrm{x}+14,519$ & 0.9991 \\
$\mathrm{ABZ}-2 \mathrm{NH}_{2}-\mathrm{SO}_{2}$ & $1.5-400.0$ & $\mathrm{y}=13,573 \mathrm{x}+32,379$ & 0.9995 \\
\hline
\end{tabular}

\subsubsection{Recovery and Precision}

The results of the recovery and precision of all analytes are summarized in Tables 3-6. As shown in Tables 3-6, when the concentrations of ABZ and its three metabolites were added to pig and poultry muscle at LOQ (the smallest LOQ among the four animal matrices), 0.5 MRL, 1.0 MRL and 2.0 MRL, the recoveries of ABZ, ABZ-SO ${ }_{2}, \mathrm{ABZ}-\mathrm{SO}$ and ABZ-2 $\mathrm{NH}_{2}-\mathrm{SO}_{2}$ were $80.37-98.39 \%, 83.13-97.68 \%, 84.65-97.93 \%$ and $83.53-97.25 \%$, respectively; the RSDs were $1.05-4.71 \%, 1.55-4.91 \%, 1.28-3.84 \%$, and $0.84-4.65 \%$, respectively; the intraday RSDs were $2.18-4.85 \%, 1.33-5.11 \%, 1.68-4.34 \%$ and $2.04-4.71 \%$, respectively; and the interday RSDs were $2.23-6.20 \%, 2.10-5.10 \%, 2.72-5.03 \%$ and $2.50-6.29 \%$, respectively.

Table 3. Recovery and precision of $\mathrm{ABZ}, \mathrm{ABZ}-\mathrm{SO}_{2}, \mathrm{ABZ}-\mathrm{SO}$ and $\mathrm{ABZ}-2 \mathrm{NH}_{2}-\mathrm{SO}_{2}$ added to blank pig muscle $(\mathrm{n}=6)$.

\begin{tabular}{|c|c|c|c|c|c|}
\hline Analyte & Adding Level $(\mu \mathrm{g} / \mathrm{kg})$ & Recovery (\%) & RSD (\%) & Intraday RSD (\%) & Interday RSD (\%) \\
\hline \multirow{4}{*}{$\mathrm{ABZ}$} & 10.0 & $80.37 \pm 1.87$ & 2.33 & 4.67 & 5.77 \\
\hline & 50.0 & $85.55 \pm 2.28$ & 2.67 & 3.42 & 6.20 \\
\hline & $100.0^{\alpha}$ & $89.67 \pm 2.12$ & 2.36 & 3.17 & 5.74 \\
\hline & 200.0 & $92.07 \pm 0.97$ & 1.05 & 2.54 & 3.56 \\
\hline \multirow{4}{*}{$\mathrm{ABZ}-\mathrm{SO}_{2}$} & 1.5 & $91.69 \pm 3.42$ & 3.73 & 4.53 & 3.54 \\
\hline & 50.0 & $93.54 \pm 3.27$ & 3.49 & 2.97 & 4.35 \\
\hline & $100.0^{\alpha}$ & $95.44 \pm 2.14$ & 2.24 & 2.15 & 3.87 \\
\hline & 200.0 & $97.08 \pm 2.02$ & 2.08 & 3.37 & 4.84 \\
\hline \multirow{4}{*}{ ABZ-SO } & 9.7 & $84.65 \pm 2.97$ & 3.51 & 4.34 & 4.77 \\
\hline & 50.0 & $91.79 \pm 1.73$ & 1.89 & 3.04 & 5.03 \\
\hline & $100.0^{\alpha}$ & $92.49 \pm 3.43$ & 3.70 & 3.17 & 3.64 \\
\hline & 200.0 & $97.93 \pm 2.73$ & 2.79 & 2.70 & 2.93 \\
\hline \multirow{4}{*}{$\mathrm{ABZ}-2 \mathrm{NH}_{2}-\mathrm{SO}_{2}$} & 3.0 & $84.56 \pm 3.93$ & 4.65 & 4.71 & 5.03 \\
\hline & 50.0 & $90.48 \pm 2.16$ & 2.39 & 2.52 & 6.29 \\
\hline & $100.0^{\alpha}$ & $96.58 \pm 1.36$ & 1.41 & 3.77 & 4.79 \\
\hline & 200.0 & $97.18 \pm 2.23$ & 2.30 & 3.10 & 4.35 \\
\hline
\end{tabular}


Table 4. Recovery and precision of $\mathrm{ABZ}, \mathrm{ABZ}-\mathrm{SO}_{2}, \mathrm{ABZ}-\mathrm{SO}$ and $\mathrm{ABZ}-2 \mathrm{NH}_{2}-\mathrm{SO}_{2}$ added to blank chicken muscle $(\mathrm{n}=6)$.

\begin{tabular}{|c|c|c|c|c|c|}
\hline Analyte & Adding Level ( $\mu \mathrm{g} / \mathrm{kg})$ & Recovery (\%) & RSD (\%) & Intraday RSD (\%) & Interday RSD (\%) \\
\hline \multirow{4}{*}{ ABZ } & 10.7 & $88.77 \pm 1.89$ & 2.13 & 2.18 & 2.63 \\
\hline & 50.0 & $89.61 \pm 2.73$ & 3.05 & 3.24 & 3.81 \\
\hline & $100.0^{\alpha}$ & $94.77 \pm 1.15$ & 1.22 & 2.85 & 3.47 \\
\hline & 200.0 & $98.39 \pm 1.50$ & 1.53 & 2.88 & 2.23 \\
\hline \multirow{4}{*}{$\mathrm{ABZ}-\mathrm{SO}_{2}$} & 1.0 & $83.13 \pm 3.94$ & 4.74 & 5.11 & 4.91 \\
\hline & 50.0 & $89.36 \pm 1.60$ & 1.79 & 2.84 & 2.10 \\
\hline & $100.0^{\alpha}$ & $94.01 \pm 3.38$ & 3.60 & 3.62 & 3.14 \\
\hline & 200.0 & $97.12 \pm 2.76$ & 2.84 & 2.89 & 2.85 \\
\hline \multirow{4}{*}{ ABZ-SO } & 8.3 & $88.08 \pm 3.38$ & 3.84 & 4.10 & 4.77 \\
\hline & 50.0 & $89.65 \pm 3.13$ & 3.49 & 3.72 & 4.11 \\
\hline & $100.0^{\alpha}$ & $94.39 \pm 2.73$ & 2.90 & 3.00 & 3.27 \\
\hline & 200.0 & $94.66 \pm 2.68$ & 2.83 & 2.88 & 3.04 \\
\hline \multirow{4}{*}{$\mathrm{ABZ}-2 \mathrm{NH}_{2}-\mathrm{SO}_{2}$} & 1.8 & $83.53 \pm 2.68$ & 3.20 & 3.57 & 3.98 \\
\hline & 50.0 & $88.88 \pm 3.35$ & 3.77 & 4.25 & 4.65 \\
\hline & $100.0^{\alpha}$ & $94.07 \pm 1.28$ & 1.36 & 2.08 & 2.95 \\
\hline & 200.0 & $95.34 \pm 1.79$ & 1.87 & 2.77 & 3.36 \\
\hline
\end{tabular}

Note: " $\alpha$ ". Maximum residue limits.

Table 5. Recovery and precision of $\mathrm{ABZ}, \mathrm{ABZ}-\mathrm{SO}_{2}, \mathrm{ABZ}-\mathrm{SO}$ and $\mathrm{ABZ}-2 \mathrm{NH}_{2}-\mathrm{SO}_{2}$ added to blank duck muscle $(\mathrm{n}=6)$.

\begin{tabular}{|c|c|c|c|c|c|}
\hline Analyte & Adding Level ( $\mu \mathrm{g} / \mathrm{kg})$ & Recovery (\%) & RSD (\%) & Intraday RSD (\%) & Interday RSD (\%) \\
\hline \multirow{4}{*}{$\mathrm{ABZ}$} & 10.0 & $89.00 \pm 2.19$ & 2.46 & 3.00 & 3.38 \\
\hline & 50.0 & $91.50 \pm 2.91$ & 3.18 & 3.64 & 3.49 \\
\hline & $100.0^{\alpha}$ & $89.60 \pm 1.64$ & 1.83 & 2.37 & 2.79 \\
\hline & 200.0 & $97.51 \pm 1.87$ & 1.92 & 2.34 & 2.69 \\
\hline \multirow{4}{*}{$\mathrm{ABZ}-\mathrm{SO}_{2}$} & 1.0 & $88.14 \pm 4.33$ & 4.91 & 4.64 & 5.10 \\
\hline & 50.0 & $90.58 \pm 3.23$ & 3.57 & 4.03 & 4.45 \\
\hline & $100.0^{\alpha}$ & $93.44 \pm 2.11$ & 2.26 & 2.62 & 2.97 \\
\hline & 200.0 & $95.55 \pm 2.00$ & 2.09 & 2.71 & 2.84 \\
\hline \multirow{4}{*}{ ABZ-SO } & 8.0 & $87.37 \pm 2.99$ & 3.43 & 3.58 & 4.02 \\
\hline & 50.0 & $93.77 \pm 2.78$ & 2.96 & 3.12 & 2.97 \\
\hline & $100.0^{\alpha}$ & $91.05 \pm 3.36$ & 3.69 & 3.88 & 4.38 \\
\hline & 200.0 & $96.20 \pm 2.68$ & 2.79 & 2.90 & 3.39 \\
\hline \multirow{4}{*}{$\mathrm{ABZ}-2 \mathrm{NH}_{2}-\mathrm{SO}_{2}$} & 1.5 & $90.84 \pm 3.60$ & 3.96 & 3.98 & 3.95 \\
\hline & 50.0 & $90.21 \pm 2.13$ & 2.36 & 2.66 & 3.04 \\
\hline & $100.0^{\alpha}$ & $95.74 \pm 1.35$ & 1.41 & 2.04 & 2.90 \\
\hline & 200.0 & $96.09 \pm 2.20$ & 2.29 & 2.27 & 2.50 \\
\hline
\end{tabular}

Note: " $\alpha$ ". Maximum residue limits.

Table 6. Recovery and precision of ABZ, ABZ-SO, $\mathrm{ABZ}-\mathrm{SO}$ and $\mathrm{ABZ}-2 \mathrm{NH}_{2}-\mathrm{SO}_{2}$ added to blank goose muscle $(\mathrm{n}=6)$.

\begin{tabular}{|c|c|c|c|c|c|}
\hline Analyte & Adding Level $(\mu \mathrm{g} / \mathrm{kg})$ & Recovery (\%) & RSD (\%) & Intraday RSD (\%) & Interday RSD (\%) \\
\hline \multirow{4}{*}{$\mathrm{ABZ}$} & 10.9 & $84.09 \pm 3.96$ & 4.71 & 4.85 & 5.36 \\
\hline & 50.0 & $88.72 \pm 2.21$ & 2.49 & 2.35 & 2.47 \\
\hline & $100.0^{\alpha}$ & $90.36 \pm 2.09$ & 2.32 & 2.40 & 3.92 \\
\hline & 200.0 & $95.09 \pm 3.62$ & 3.81 & 4.27 & 4.71 \\
\hline \multirow{4}{*}{$\mathrm{ABZ}-\mathrm{SO}_{2}$} & 1.0 & $89.11 \pm 1.59$ & 1.79 & 1.33 & 3.80 \\
\hline & 50.0 & $93.84 \pm 2.17$ & 2.31 & 2.34 & 2.56 \\
\hline & $100.0^{\alpha}$ & $95.19 \pm 2.63$ & 2.76 & 2.62 & 2.92 \\
\hline & 200.0 & $97.68 \pm 1.51$ & 1.55 & 1.67 & 3.50 \\
\hline \multirow{4}{*}{ ABZ-SO } & 8.5 & $87.98 \pm 3.32$ & 3.78 & 3.89 & 4.07 \\
\hline & 50.0 & $88.37 \pm 1.13$ & 1.28 & 1.68 & 3.40 \\
\hline & $100.0^{\alpha}$ & $92.49 \pm 2.63$ & 2.85 & 3.76 & 3.42 \\
\hline & 200.0 & $97.03 \pm 2.15$ & 2.21 & 2.11 & 2.72 \\
\hline \multirow{4}{*}{$\mathrm{ABZ}-2 \mathrm{NH}_{2}-\mathrm{SO}_{2}$} & 1.9 & $91.83 \pm 3.24$ & 3.53 & 3.56 & 3.63 \\
\hline & 50.0 & $92.03 \pm 2.70$ & 2.94 & 2.91 & 3.06 \\
\hline & $100.0^{\alpha}$ & $94.26 \pm 2.30$ & 2.44 & 2.77 & 3.11 \\
\hline & 200.0 & $97.25 \pm 0.81$ & 0.84 & 2.47 & 3.41 \\
\hline
\end{tabular}




\subsection{Real Sample Analysis}

To evaluate the feasibility and applicability of the new method, 40 samples each of chicken, duck, goose and pig muscle were analyzed by the developed method and were purchased from a local supermarket. Only two chicken muscle samples were found to contain $\mathrm{ABZ}-2 \mathrm{NH}_{2}-\mathrm{SO}_{2}$ residues (11.3 and $14.6 \mu \mathrm{g} / \mathrm{kg}$ ), one pig muscle sample was found to contain ABZ-2 $2 \mathrm{NH}_{2}-\mathrm{SO}_{2}$ residues $(11.8 \mu \mathrm{g} / \mathrm{kg})$, and none of the samples exceeded the MRL of $100 \mu \mathrm{g} / \mathrm{kg}$ (EU standard). Therefore, the novel UPLC-FLD method is reliable for application according to a real sample analysis.

\section{Conclusions}

A fast and effective LLE-SPE preparation method coupled with UPLC-FLD was established for detecting multiple residues of $\mathrm{ABZ}$ and its three metabolites in pig and poultry muscle. The extraction method exhibited high extraction efficiencies and recoveries, and the obtained recoveries of $\mathrm{ABZ}$ and its three metabolites in pig and poultry muscle were all greater than $80.37 \%$. This LLE-SPE-UPLC-FLD method provides a new method for the simultaneous detection of ABZ and its three metabolites in pig and poultry muscle, and this method was found to have relatively high sensitivity and precision and a short detection time. Moreover, the newly developed method was successfully applied to the analysis of real samples, which proved the applicability of this method.

Author Contributions: Conceptualization, Z.H. and K.X.; methodology, Z.H. and Z.D.; software, Z.H.; validation, C.X., L.C. and Y.L.; formal analysis, Z.H.; investigation, J.C.; resources, T.Z.; data curation, Y.G.; writing —original draft preparation, Z.H.; writing—review and editing, Z.H. and Y.G.; funding acquisition, K.X. All authors have read and agreed to the published version of the manuscript.

Funding: This research was financially supported by the China Agriculture Research System of MOF and MARA (CARS-41), the Priority Academic Programme Development of Jiangsu Higher Education Institutions (PAPD), and the Yangzhou University High-End Talent Support Program.

Informed Consent Statement: The study was conducted according to the guidelines of the Declaration of Helsinki, and approved by the Institutional Animal Care and Use Committee (IACUC) of the government of Jiangsu Province (Permit Number 45) and Ministry of Agriculture of China (Permit Number 39).

Conflicts of Interest: The authors declare no conflict of interest.

\section{References}

1. Romero, T.; Althaus, R.; Moya, V.J.; Beltrán, M.C.; Reybroeck, W.; Molina, M.P. Albendazole residues in goat's milk: Interferences in microbial inhibitor tests used to detect antibiotics in milk. J. Food Drug Anal. 2017, 25, 302-305. [CrossRef]

2. Permana, A.D.; Tekko, I.A.; McCarthy, H.O.; Donnelly, R.F. New HPLC-MS method for rapid and simultaneous quantification of doxycycline, diethylcarbamazine and albendazole metabolites in rat plasma and organs after concomitant oral administration. $J$. Pharm. Biomed. Anal. 2019, 170, 243-253. [CrossRef]

3. Goldstein, P. Loss of the central rachis and synaptonemal complexes during meiotic prophase in female Ascaris lumbricoides var. suum after exposure to albendazole. J. Helminthol. 2021, 95, E32. [CrossRef]

4. Bistoletti, M.; Alvarez, L.; Lanusse, C.; Moreno, L. Disposition kinetics of albendazole and metabolites in laying hens. J. Vet. Pharmacol. Ther. 2012, 36, 161-168. [CrossRef] [PubMed]

5. Piloiu, C.; Dumitrascu, D.L. Albendazole-induced liver injury. Am. J. Ther. 2021, 28, e335-e340. [CrossRef] [PubMed]

6. Carlsson, G.; Patring, J.; Ullerås, E.; Oskarsson, A. Developmental toxicity of albendazole and its three main metabolites in zebrafish embryos. Reprod. Toxicol. 2011, 32, 129-137. [CrossRef] [PubMed]

7. Chassaing, C.; Berger, M.; Heckeroth, A.; Ilg, T.; Jaeger, M.; Kern, C.; Schmid, K.; Uphoff, M. Highly water-soluble prodrugs of anthelmintic benzimidazole carbamates: Synthesis, pharmacodynamics, and pharmacokinetics. J. Med. Chem. 2008, 51, 1111-1114. [CrossRef] [PubMed]

8. GB 31650-2019; National Food Safety Standard. Maximum Residue Limits for Veterinary Drugs in Foods; Ministry of Agriculture and Rural Afairs of the People's Republic of China: Beijing, China, 2019.

9. The European Medicines Agency. Commission Regulation (EU) No. 37/2010 of 22 December 2009 on Pharmacologically Active Substances and their Classification Regarding Maximum Residue Limits in Foodstuffs of Animal Origin; The European Medicines Agency: London, UK, 2010. 
10. Romvfiri, Z.; Kemény, S.; Pokol, G.; Fekete, J. A new approach for development of rugged sample preparation of metabolites of albendazole in cow milk. Microchim. Acta 1999, 130, 155-163. [CrossRef]

11. Permana, A.D.; Wahyudin, E.; Ismail; Amir, M.N.; Raihan, M.; Anjani, Q.K.; Utomo, E.; Layadi, P.; Donnelly, R.F. New and sensitive HPLC-UV method for concomitant quantification of a combination of antifilariasis drugs in rat plasma and organs after simultaneous oral administration. Anal. Methods 2021, 13, 933-945. [CrossRef]

12. Fletouris, D.J.; Botsoglou, N.A.; Psomas, I.E.; Mantis, A.I. Determination of the marker residue of albendazole in cheese by ion-pair liquid chromatography and fluorescence detection. J. Dairy Sci. 1997, 80, 2695-2700. [CrossRef]

13. Asadi, M.; Dadfarnia, S.; Haji Shabani, A.M. Simultaneous extraction and determination of albendazole and triclabendazole by a novel syringe to syringe dispersive liquid phase microextraction-solidified floating organic drop combined with high performance liquid chromatography. Anal. Chim. Acta 2016, 932, 22-28. [CrossRef]

14. Shaikh, B.; Rummel, N.; Reimschuessel, R. Determination of albendazole and its major metabolites in the muscle tissues of Atlantic salmon, tilapia, and rainbow trout by high performance liquid chromatography with fluorometric detection. J. Agric. Food Chem. 2003, 51, 3254-3259. [CrossRef]

15. Fletouris, D.J.; Botsoglou, N.A.; Psomas, I.E.; Mantis, A.I. Determination of the marker residue of albendazole in milk using ion-pair liquid chromatography and fluorescence detection. Anal. Chim. Acta 1997, 345, 111-119. [CrossRef]

16. Rummel, N.; Chung, I.; Shaikh, B. Determination of albendazole, fenbendazole, and their metabolites in mouse plasma by high performance liquid chromatography using fluorescence and ultraviolet detection. J. Liq. Chromatogr. Relat. Technol. 2011, 34, 2211-2223. [CrossRef]

17. Xu, N.; Dong, J.; Yang, Y.; Liu, Y.; Yang, Q.; Ai, X. Development of a liquid chromatography-tandem mass spectrometry method with modified QuEChERS extraction for the quantification of mebendazole and its metabolites, albendazole and its metabolites, and levamisole in edible tissues of aquatic animals. Food Chem. 2018, 269, 442-449. [CrossRef]

18. Msagati, T.A.M.; Nindi, M.M. Comparative study of sample preparation methods; supported liquid membrane and solid phase extraction in the determination of benzimidazole anthelmintics in biological matrices by liquid chromatography-electrospraymass spectrometry. Talanta 2006, 69, 243-250. [CrossRef] [PubMed]

19. Jedziniak, P.; Szprengier-Juszkiewicz, T.; Olejnik, M. Determination of benzimidazoles and levamisole residues in milk by liquid chromatography-mass spectrometry: Screening method development and validation. J. Chromatogr. A 2009, 1216, 8165-8172. [CrossRef] [PubMed]

20. Kinsella, B.; Lehotay, S.J.; Mastovska, K.; Lightfield, A.R.; Furey, A.; Danaher, M. New method for the analysis of flukicide and other anthelmintic residues in bovine milk and liver using liquid chromatography-tandem mass spectrometry. Anal. Chim. Acta 2009, 637, 196-207. [CrossRef] [PubMed]

21. Wojnicz, A.; Cabaleiro-Ocampo, T.; Román-Martínez, M.; Ochoa-Mazarro, D.; Abad-Santos, F.; Ruiz-Nuño, A. A simple assay for the simultaneous determination of human plasma albendazole and albendazole sulfoxide levels by high performance liquid chromatography in tandem mass spectrometry with solid-phase extraction. Clin. Chim. Acta 2013, 426, 58-63. [CrossRef] [PubMed]

22. The European Communities. Commission decision 2002/657/EC of 12 august 2002 implementing council directive 96/23/EC concerning the performance of analytical methods and the interpretation of results. Off. J. Eur. Union 2002, $221,8-36$.

23. Zhang, H.; Zhao, J.; Chen, B.; Ma, Y.; Li, Z.; Shou, X.; Wen, L.; Yuan, Y.; Gao, H.; Ruan, J.; et al. Pharmacokinetics and tissue distribution study of liposomal albendazole in naturally Echinococcus granulosus infected sheep by a validated UPLC-Q-TOF-MS method. J. Chromatogr. B 2020, 1141, 122016. [CrossRef] [PubMed]

24. Rummel, N.; Shaikh, B. Determination of albendazole and its metabolites in the muscle tissue of hybrid striped and largemouth bass using liquid chromatography with fluorescence detection. J. AOAC Int. 2008, 91, 469-478. [CrossRef] [PubMed]

25. Batzias, G.C.; Delis, G.A. Reversed-phase liquid chromatographic method with fluorescence detection for the simultaneous determination of albendazole sulphoxide, albendazole sulphone and albendazole 2-aminosulphone in sheep plasma. J. Chromatogr. B 2004, 805, 267-274. [CrossRef]

26. Vichapong, J.; Santaladchaiyakit, Y.; Burakham, R.; Kanchanamayoon, W.; Srijaranai, S. Determination of benzimidazole anthelmintics using HPLC after vortex-assisted mixed anionic-cationic surfactant-enhanced emulsification microextraction with solidification of floating organic droplet procedure. J. Food Compos. Anal. 2015, 37, 30-37. [CrossRef] 